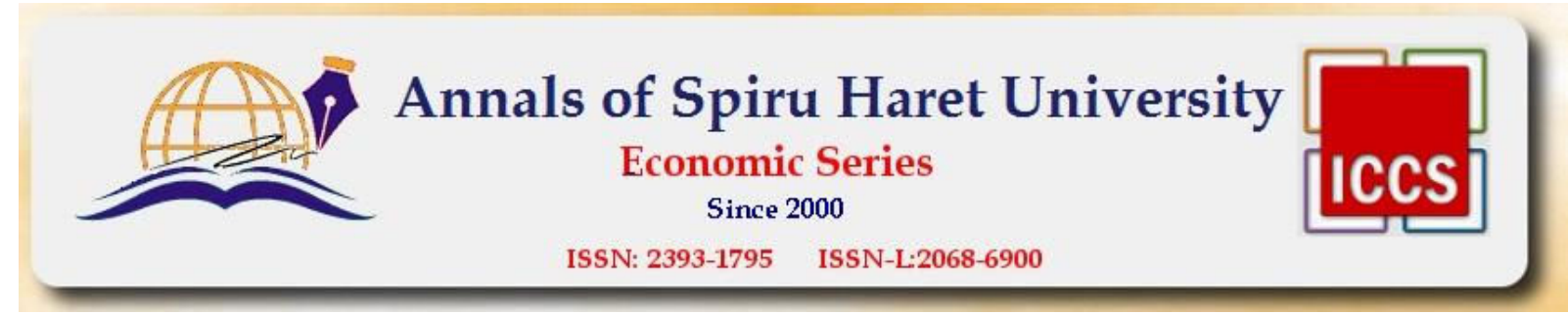

Issue 4/2016

\title{
UNDERSTANTING THE NOTION OF STATE AID AND ITS CORRECT APPLICATION
}

\author{
Adrian Ştefan ENE \\ MA Student, "Spiru Haret" University, Faculty of Economic Sciences, \\ Bucharest, Romania, Email: stanefrid@gmail.com
}

\begin{abstract}
The purpose of the present paper has the following objectives:

- to deepen the understanding of the notion of state aid according to article 107, paragraph 1 from the Treaty on the Functioning of the European Union definition;

- how the European Union legislation is directly applicable to the Romanian legislation through the Guide Regarding State aid ${ }^{1}$ and the Emergency Ordinance no. 77/201;

- how it is applied through the state aid schemes namely Decision no. 807/2014 and $332 / 2014$.
\end{abstract}

Keywords: state aid, European Union Treaty.

JEL Classification: O0, G1

\section{Introduction}

This paper covers the notion of state aid and how it applies in the current national and international economic context, by creating a comprehensive understanding of what state aid is, defined according to the Treaty on the Functioning of the European Union, article 107, paragraph 1 and through the Emergency Ordinance no. 77/2014. And also how state aid applies in Romania through the two schemes, namely Decision no. 807/2014 and Decision no. 332/2014.

The study is based on economic and legislative information gathered and extracted from the Treaty on the Functioning of the European Union, national legislature and the Guide Regarding state aid (only in Romanian). According to the Treaty on the Functioning of the European Union, article 107, paragraph 1 defines the notion of state aid as follows: Save as otherwise provided in the Treatise, any aid granted by a Member state or through State resources in any form whatsoever which distorts competition by favouring certain undertakings or the production of certain goods shall, in so far as it affects trade between Member States, be incompatible with the internal market. As a recent member of European Union, Romania considers itself an affiliated part of corresponding international agreements.

The European Union Law for State aid is implemented through regulations, recommendations, communications, guidelines, agreements, directives, decisions from the European Commission, which provide a comprehensive understanding of the notion of state aid in all economic fields, being regularly update. The Ministry of Public Finances, through the General Directorate for state aid, uses, as their primary regulatory action, the Emergency Ordinance no. 77/2014 regarding national procedures in state aid field and the amendment and completion of the Competition Law no. 21/1996, with the consequent modification and completion.

\footnotetext{
${ }^{1}$ Developed by the Competition Council, available only in Romanian.
} 


\section{Annals of Spiru Haret University \\ Economic Series \\ Since 2000}

ISSN: 2393-1795 ISSN-L:2068-6900

Issue 4/2016

State aid - definition ${ }^{2}$

State aid rules apply only to measures that satisfy all of the criteria listed in Article 107(1) of the Treaty on the Functioning of the European Union (TFEU), respectively:

(a) State resources

Financial transfers that constitute aid can take many forms: grants or interest rate rebates, loan guarantees, accelerated depreciation allowances, capital injections, tax exemptions etc.

\section{(b) Economic advantage}

State aid is considered an economic advantage for a company that under normal competitive market conditions would not have benefit from it, e.g. an enterprise obtains risk capital from the state on terms which are more favourable than it would obtain from a private investor.

\section{(c) Selectivity}

A scheme is considered "selective", if the authorities administering the scheme enjoy a degree of discretionary power. The selectivity criterion is also satisfied if the scheme applies to only part of the territory of a Member State.

\section{(d) Effect on competition and trade}

A measure of state aid is regarded as distorting competition when the quantum amount granted exceeds the threshold of 200 thousand Euros.

\section{The relation between the state aid, competition and market failure}

The existence of state aid legislature is essential for the well-being and protection of the Single Market, especially under the conditions in which in this market operates millions of consumers. The existence of a competitive environment in which the interventions of the Member States can be accomplished without any common rules will establish a fragmented market, which will stop growth and economic development of the Single Market and ultimately it will determine a fierce competition between the Member States of providing grants.

In a functioning market economy, competition occurs both on the products market and services market, as well as geographically, and in areas where the reach depends on the product characteristics (price of the product, shipping cost, size, etc.).

Establishing a market price is accomplished by using the mechanisms of supply and demand. The established price should ensure a reasonable coverage of demand and should be bearable for consumers, but should also assure an acceptable level of profitability for the manufacturers. Therefore, is safe to say that the competition between manufacturers of products and of services manifests at the market price. One way competition works is by placing all the manufacturers under a beneficial competitive pressure, which determines them to seek to attain a market value based upon quality. Therefore, the manufacturing price and the final product price have the ultimate goal to cover the demand, which manifest on the market, in the highest way possible.

If the manufacturers try to draw in a larger number of clients, they will have to reduce the products and services' retail prices. So, in order for the manufacturer to be competitive they must lower the production costs.

${ }^{2}$ The definition of state aid considers the Art. 107 of the Treaty on the Functioning of the European Union as it is given by the Romanian Competition Council (English version), which can be found following the next link: http://www.renascc.eu/?pag=100\&limba=en 


\section{Annals of Spiru Haret University \\ Economic Series \\ Since 2000}

ISSN: 2393-1795 ISSN-L:2068-6900

Issue 4/2016

The state, on the other hand, is interested in insuring, defending and promoting the public interest, therefore, the state involves itself in contributing in developing a society which:

- has a balanced regional economic and social development;

- can create sufficient jobs, well paid and regulated in terms of labour protection;

- has staff employee's or potential employees well trained, with an adaptable knowledge base on the continual changing requirements on the labour market;

- can create diverse and modern products and services adequate to the consumer needs with an acquisition cost that can be affordable to a larger consumer crowd;

- has utilities of any nature and quality that are available to all citizens at reasonable prices;

- has or will have an infrastructure which enables in good condition the ongoing economic and social life;

- can reduce the number of unemployed staff to a minimum, and the disadvantaged in terms of employability can be integrated, under certain conditions, on the labour market;

- can provide a clean, conducive to human life environment in which the citizens work;

- can provide education and culture to a larger number of citizens, etc.

The state has at some percentage the resources needed to achieve some of the previous objectives; in order to achieve the rest, the state needs the involvement of the private sector.

If the economic activity is run in good conditions, it determines the entrepreneurs to adopt by themselves measures that can achieve a part of the objectives of the state or society in which they operate. Thereby, creating new jobs, maintaining them, ensuring the proper conditions of work to the employees is, oftentimes, in the interest of the entrepreneurs, which in turn contributes to the fulfilment of the public interest. In order to ensure their staff well-trained, capable to operate new machinery and to implement new technology, the entrepreneurs invest in the training of its employees. But because the investments of the entrepreneurs are limited to certain areas that can generate profit, market failures can be defined by those sectors in which competitiveness does not manifest nor does it lead to the public interest fulfilment. Because of this, market failures cannot be solved by the private sector or entrepreneurs, who do not have the economic interest in investing, in solving or in diminishing market failures; knowing that in doing so, this will affect their competitiveness and will diminish their profits.

Therefore, the state has the role in solving or diminishing market failures, through the next two options.

a. Statutory regulation for certain sectors, areas, activities in which market failures manifest; for example, the state imposes labour market regulations (sets the minimum wage, the minimum number of days of leave, length of a working day and that the employer must train his employees on his own financial resources in the field of occupational safety and labour protection) which the employer must respect.

b. Financial compensation of certain market failures; this can be achieved when the state grants quantifiable benefits to companies with the purpose of raising the interest of these companies to invest their own capital in conducting certain activities that are not considered at baseline cost. The granting of such benefits may easily take the form of state aid; therefore, the state, must always be able to identify a causal link between granting the state aid and the market failures to which it addresses.

The appropriateness of granting state aid, their amount and how concrete or the most appropriate instrument for the aid are required to be established through analyzes and studies carried out before the establishment of the real openness towards facilities. One of the foremost criteria's that the European Commission, when they analyze the effects of granting the various categories of state aid, is the prevalence of the positive effects over the negative effects. 


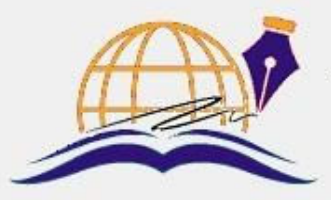

Annals of Spiru Haret University

Economic Series

Since 2000

ISSN: 2393-1795 ISSN-L:2068-6900

Issue 4/2016

The typology of market failures and the ways of their diminishing using the state aids

a. Less developed regional areas which attract fewer investments are counterbalanced by the state through national regional investment aid.

Differences between the level of development of different geographical areas manifest both on an European and national level; both of which have developed regional areas, favourable to economic activities, with a well developed infrastructure, high income and a high level of production relative to population, business opportunities materialized in easy access to the resources necessary to conduct and develop technological processes, a numerous and well prepared existing workforce and the existence of markets for products and services. While the less developed regional areas are characterized through insufficient infrastructure, a low income and level of production relative to population, the inexistence or reduced existence of business opportunities with difficult access to resources necessary for developing technological processes, numerically reduced workforce and/or with insufficient training, and underdeveloped markets for products and services.

Therefore a rational entrepreneur or investor will avoid investing in a less developed area and will chose to invest in a developed area, which will create an even bigger development gap between the two.

Considering the fact that the state has the interest in promoting a balanced development throughout all the regional areas of its country, it will try to determine the investors or the entrepreneurs to invest in the less developed areas. This can be achieved through granting national regional investment aid, if the investors or entrepreneurs choose to invest in less developed areas.

b. Under-funded financial sectors and crisis of overproduction

Because the necessary investments to operate in some economic areas are oftentimes significant, investors choose to invest in areas which guarantee the return of the investment.

One such case is that of providing broadband electronic communications, in which the investors develop their own networks, primarily in urban and adjacent areas where there is a significant population that can provide them creditworthy potential clients. Therefore, because of the significant investment, the investor will avoid to invest in areas less developed, located far from the main networks. Therefore, the state will try to help develop broadband electronic communication networks by subsidizing part of the cost of creating them or may cover some of the cost of connecting end-user to networks already created; this type of aid is called state aid for rapid development of broadband communications networks.

On the other hand, some economic sectors face a crisis of overproduction when the demand of some products or services drops dramatically or they are no longer required on the market.

This is the case of the coal sector, where the reduction of coal consumption has caused lately the ceasing of a significant number of mines. In this case, the aid that the state can provide has the role to ensure environmental protection and avoid potential disaster caused by the deterioration of unused mining infrastructure by providing the costs of closing the coal mines which stopped their activity. Both of the cases mentioned above are examples of sectoral state aid.

\section{c. Difficult access to finance of the small and medium enterprises}

Because first starting an economic activity requires somewhat significant financial resources for an investor and because the recovery of the initial investment could take a considerable amount of time, this forces the investor to attract financial resources from the financial market, especially from the banking sector. The banks tend to lend investors the required amounts only under sufficient guarantees that the amounts borrowed will be repaid, making it difficult for an entrepreneur to start a new activity.

Therefore, the state, considering the importance of the small and medium enterprises sector for the national economy, can decide to grant different facilities to the entrepreneurs in order for them to develop their own activities; this facility can take the form of grants, subsidized loans or guarantees at 


\section{2 Annals of Spiru Haret University Economic Series \\ Since 2000 \\ ISSN: 2393-1795 ISSN-L:2068-6900}

Issue 4/2016

a reduced cost compared to the level charged by commercial banks. These kinds of facilities are called State aid for SMEs ${ }^{3}$.

\section{d. Companies in financial difficulty with the impossibility of continuing activities}

When companies are in financial difficulty with the impossibility of continuing activities, some of them can be saved by technological restructuring in parallel with the injection of capital.

If the state funds or facilitates loans or guarantees for the benefit of companies in difficulty at prices lower than those prevailing in the market, given their rescue and restructuring, these are called state aid for rescuing and restructuring.

\section{e. Utilities and some services which are not provided or their market price is too high}

Because a number of utilities, like thermal energy, can be prohibitive to families with low income considering the relatively high production price, the state must regulate a maximum supply price which sometimes is below the cost price charged by the heat producers.

Therefore, in order for the producers to continue conducting business in terms of quality and economic profitability, the state can compensate a percentage of the production cost of the service they produce. This type of aid can take the form of compensations to companies for the provision of a service obligation or a service of general economic interest (SGEI).

\section{f. Disadvantaged workers which are not employed by entrepreneurs}

Some categories of workers are consider disadvantaged from the point of view of employability, this is the case of people who did not have a stable job paid in the last 6 months, or they are aged between 15 and 24 years, they did not graduated any form of high school or hold a professional qualification and also are in the first two years since they graduated and did not have a stable paid job, they are above 50 years old, or they live alone having one or more persons in their care. Also a number of employees fall into the category of disabled or handicapped workers.

The difficulties in entering the labour market for the above categories can vary from arranging special working conditions necessary to the staff with disabilities, to higher training costs in the development of certain skills, or lower revenue generation. The state compensates this employment disadvantages by determining the undertakings to employ staff from the categories mentioned above through granting aids for the recruitment and employment of disadvantaged workers and workers with disabilities.

\section{g. Training is not a priority for companies}

Companies tend to keep production costs under strict control, in such a way as to reduce the price of goods and services sold, to increase their competitiveness and ultimately maximize the profits from the economic activity in which they are engaged. Thus, the amounts of investments in training their staff are reduced.

However, the state has among his objectives, raising the level of the whole population engaged and, therefore, can subsidize fully or partially vocational training cost, by providing state aid for training.

\section{h. Research is not encouraged}

Similar to vocational training, companies will invest in research only sporadically, within immediate needs of development of new products and services. Therefore, the research conducted will have a highly applicable component, financially quantifiable in a reasonable time horizon providing investors with a quick initial investment recovery, new innovative products and services, additional revenues and profits and other benefits.

\footnotetext{
${ }^{3}$ SMEs means Small and Medium Enterprises.
} 


\section{Annals of Spiru Haret University \\ Economic Series \\ Since 2000}

ISSN: 2393-1795 ISSN-L:2068-6900

Issue 4/2016

Also in this case the state can subsidize a percentage of the research costs undertaken by the companies, through state aid for research, development and innovation.

i. The environment is not protected

The running technological processes often generate gas and particle emissions that contribute to environmental damage. Therefore, there were established national, international regulations which establish corporate responsibility both in terms of reducing the amount of pollutants and in terms of penalties that will be incurred under the contravention charging rules.

The state will not provide funding to cover costs that enterprises must bear by virtue of their obligations imposed by the national and international legal regulations. However, the state can subsidize businesses to improve environmental protection through overcoming the environmental standards such as increasing the energy efficiency, promotion of energy production from renewable sources and reducing industrial pollution. These facilities granted by the state are called state aid for environmental protection and energy efficiency.

\section{The Emergency Ordinance no. 77/2014 - the mirror of EU Recommendation in the field of the state aid}

In close correlation with European Union recommendations, by Emergency Ordinance no. $77 / 2014$, the Romanian Government decided to harmonize the process of modernization of the state aid by applying the requirements of minimis ${ }^{4}$.

The provisions of the above mentioned regulatory action do not apply to state aid or de minimis for agriculture and fisheries, for which the Ministry of Agriculture and Rural Development fulfils the role of national contact in relations between the European Commission and public authorities and institutions, and other state aid providers.

The establishment of state aid or de minimis measures will be made after the analysis of opportunities and requires the initiator or supplier to develop legislation or administrative regulatory actions. Regulatory actions establish state aid/individual state aid or individual/de minimis schemes which should provide at least the following: objective, how to grant state aid or de minimis, beneficiaries, the application, the amount of funds allocated for this purpose in the budget provider, the European applicable provision under which the state aid or de minimis aid measure was instituted in accordance with the legislation field.

Any state aid measure instituted by the central public authorities, except the central public authorities who manage European funds ${ }^{5}$, must be accompanied by a Memorandum approved by the Government on the framing of the support measure in economic, financial and budgetary policies of the state ${ }^{6}$. The procedure and the content of the Memorandum will be established through a Government decision and will be initiated each semester by the $\mathrm{SGG}^{7}$, after consulting the suppliers in the Interministerial Council, "The Council for the implementation policy in the field of state aid".

The Emergency Ordinance no. 77/2014 also states the need to introduce a stage of preliminary consultations between aid providers and the experts from the Competition Council ${ }^{8}$. The consultations between aid providers and the experts from the Competition Council identify the measures on how the aid measure can be implemented. The consultations benefits lead to:

$>$ developing measures to support compliance with state aid legislation;

$>$ issuing licenses by the Competition Council in a shorter term;

${ }^{4}$ De minimis Aid is the type of aid which is under EU rules limited to a level that does not distort competition and or trade with the Member States.

${ }^{5}$ Emergency Ordinance no.77/2014, Article 7, paragraph (4).

${ }^{6}$ Emergency Ordinance no.77/2014, Article 7, paragraphs (1),(3),(5).

${ }^{7}$ Secretary General of the Government.

${ }^{8}$ Emergency Ordinance no.77/2014, Article 8. 


\section{Annals of Spiru Haret University \\ Economic Series \\ Since 2000 \\ ISSN: 2393-1795 ISSN-L:2068-6900}

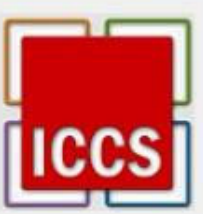

Issue 4/2016

more legal certainty in the implementation of state aid or non-state aid measures.

The proper procedure of notification and information is sent electronically to the European Commission by state aid Notification Interactive (SANI II) through the Competition Council.

The monitoring of the state aid or de minimis is done for each measure, by either the provider or the administrator. On the spot checks are done to insure the monitoring measures and conditions for the state aid granted. If the measures and conditions are not carried on, the state aid is recovered.

The aid recipient is obliged to repay the state aid/de minimis with the related aid interest.

Both the beneficiary and the provider or the administrator of the state aid/de minimis aid must keep a database with the related aids granted for at least 10 years.

Currently, the Ministry of Public Finances implements several state aid schemes, of which we exemplify Decision no. 807/2014 and Decision no. 332/2014.

The Decision no. 807/2014 about how certain state aid schemes are established to stimulate investments with a major economic impact

The primary objective of the scheme is regional development through the performance of investments in all sectors, with the total estimated number of beneficiaries to this scheme of 150 . Undertakings can apply for funding under this scheme until December 2020 with the pay being executed until 2023. To meet the scheme conditions of eligibility the assets must fulfil the following9:

a) the beneficiary of state aid must not sell the assets for which it received financial help;

b) the beneficiary of state aid has the obligation to record the assets in its accounting and to keep them at least 5 years;

c) the beneficiary must purchase the assets under public procurement legislation.

Assets are either tangible assets which can be constructions of any kind, the expenditure for the execution of constructions like new technical installations, machines and equipment and intangible assets which are patents, licenses, know-how or other intellectual property. ${ }^{10}$ Also the assets must be purchased from persons that are not affiliated to the buyers.

The maximum level of the state aid an enterprise can benefit of within the scheme is the following corresponding to the eligible expenditure ${ }^{11}$ :

\begin{tabular}{|c|c|c|}
\hline \multirow{2}{*}{ Region } & \multicolumn{2}{|c|}{ Maximum level of state aid } \\
\cline { 2 - 3 } & $2014-2017$ & $2018-2020$ \\
\hline Bucharest Region & $\begin{array}{c}\text { the equivalent in } \\
\text { Lei of EUR 11.25 million }\end{array}$ & $\begin{array}{c}\text { the equivalent in Lei of EUR 7.5 } \\
\text { million }\end{array}$ \\
\hline $\begin{array}{c}\text { West Region and } \\
\text { Ilfov Region }\end{array}$ & the equivalent in Lei of EUR 26.25 million \\
\hline $\begin{array}{l}\text { Regions NW, } \\
\begin{array}{l}\text { Centre, NE, SE, South } \\
\text { Muntenia, SW Oltenia }\end{array}\end{array}$ & the equivalent in Lei of EUR 37.5 million \\
\hline
\end{tabular}

\footnotetext{
${ }^{9}$ Decision no. 807/2014, Articles 1, 3 and 5.

${ }^{10}$ Decision no. 807/2014, Appendices 2, Article 1 letters a), b).

${ }^{11}$ Decision no. 807/2014, Article 9 paragraph (1).
} 


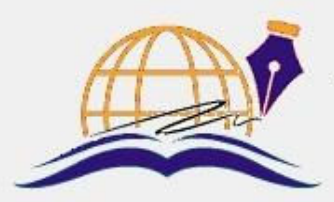

Annals of Spiru Haret University

Economic Series

Since 2000

ISSN: 2393-1795 ISSN-L:2068-6900

\section{Issue 4/2016}

The gross intensity of the regional state aid relative to the eligible expenditure cannot exceed the following percentages ${ }^{12}$ :

\begin{tabular}{|l|c|c|}
\hline \multirow{2}{*}{ Region } & \multicolumn{2}{|c|}{ Maximum level of state aid } \\
\cline { 2 - 3 } & 2017 & $2018-2020$ \\
\hline Bucharest Region & $15 \%$ & $10 \%$ \\
\hline $\begin{array}{l}\text { West Region and } \\
\text { Ilfov Region }\end{array}$ & $35 \%$ \\
\hline $\begin{array}{l}\text { Regions NW, Centre, NE, SE, South } \\
\text { Muntenia, SW Oltenia }\end{array}$ & $50 \%$ \\
\hline
\end{tabular}
once. ${ }^{13}$

Contribution to regional development must exceed the state aid granted to companies at least

The state aids are granted only if they have a challenging effect, which can be determined through a comparative analysis between two company projects, one with the intervention of the state and the other without.

One of the conditions that a company must meet in order to obtain the agreement for funding, is to not proceed with the investment prior to obtaining consent for funding.

For a company to benefit from state aid, it must meet several criteria's in order to be eligible, including: the company must make an investment in the sectors the scheme permits, the company must be registered under the laws of Romania, the company must not be in bankruptcy or insolvency and it must not have debts to the state or local budgets. costs. ${ }^{14}$

Also for a company to benefit from the approved state aid, it must achieve partial or total eligible

For an enterprise to benefit from the payment of the approved state aid, it must submit a request for payment accompanied by the following documents:

a) tax certificates which demonstrates that the company has no debts to the state;

b) the company's balance sheet and balance;

c) a form in which are the prescribed costs incurred by the company and the state aid requested to be paid;

d) any other documents that the company deems evidence for eligible expenditures.

The enterprises are entitled to at most two payment requests for the approved state aid within one calendar year.

For payments the Ministry of Public Finances examines the compliance documents submitted by the undertaking and solves the enterprises application after conducting a spot check to verify the truthfulness and conformity of the documents submitted.

The enterprise must maintain operational the initial investment made for at least 5 years since the date of its completion.

In case a company cannot fulfil the investment plan which was approved, it may submit an amendment to the plan by the Ministry of Public Finances. This then is examined by the Ministry if the information changed is accurate and complete, in this case granting the new agreement. The undertaking may submit under this scheme up to two plan changes. In case the change of plan documentation is not correct and complete, the Ministry of Public Finance revokes the finance agreement.

\footnotetext{
${ }^{12}$ Decision no. 807/2014, Article 10 paragraph (1).

${ }^{13}$ Decision no. 807/2014, Article 12.

${ }^{14}$ Decision no. 807/2014, Appendices 2 Chapter III Article 9.
} 


\section{Annals of Spiru Haret University \\ Economic Series \\ Since 2000 \\ ISSN: 2393-1795 ISSN-L:2068-6900}

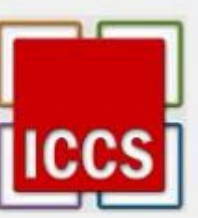

Issue 4/2016

The state aid paid will be proportionally recovered, up to the degree of non-realization if the enterprise does not realize the contribution to regional development and the enterprise does not fulfil other requirements provided by the financing agreement.

Decision no. 332/2014 regarding how the state aid scheme is established to support investments and promote regional development through the creation of jobs

The purpose of this scheme is regional development through investments that help create jobs in all sectors.

The Ministry of Public Finance may issue financing agreements until December 2020. The state aid is to be paid between 2015 and 2025, based on the financing agreements issued beforehand, within the limit of the annual budget allocated to the scheme. ${ }^{15}$ With a total estimated number of enterprises which will benefit from state aid based on the scheme of $1.700 .{ }^{16}$

The eligible expenditure is considered the newly created jobs for a period of two consecutive years.

The maximum level of the state aid an enterprise can benefit of within the scheme is the following corresponding to the eligible expenditure ${ }^{17}$ :

\begin{tabular}{|l|l|l|}
\hline \multirow{2}{*}{ Region } & Maximum level of state aid \\
\cline { 2 - 3 } & $2014-2017$ & $2018-2020$ \\
\hline Bucharest Region & the equivalent in Lei of EUR 11.25 million & $\begin{array}{l}\text { the equivalent in } \\
\text { Lei of EUR 7.5 } \\
\text { million }\end{array}$ \\
\hline West Region and Ilfov Region & the equivalent in Lei of EUR 26.25 million \\
\hline $\begin{array}{l}\text { Regions NW, Centre, NE, SE, } \\
\text { South Muntenia, SW Oltenia }\end{array}$ & the equivalent in Lei of EUR 37.5 million \\
\hline
\end{tabular}

The percentages of the regional state aid intensity depending on the regions, that the companies can benefit, are as follows ${ }^{18}$ :

\begin{tabular}{|l|l|l|}
\hline \multirow{2}{*}{ Region } & \multicolumn{2}{|c|}{ Maximum level of State aid } \\
\cline { 2 - 3 } & $2014-2017$ & $2018-2020$ \\
\hline Bucharest Region & $15 \%$ & $10 \%$ \\
\hline $\begin{array}{l}\text { West Region and } \\
\text { Ilfov Region }\end{array}$ & $35 \%$ & \\
\hline $\begin{array}{l}\text { Regions NW, Centre, } \\
\text { NE, SE, South Muntenia, } \\
\text { SW Oltenia }\end{array}$ & $50 \%$ & \\
\hline
\end{tabular}

The state aids are granted only if they have a challenging effect, and if the following conditions are cumulatively fulfilled:

a) the undertaking must submit a request for funding along with the related documentation to the Ministry of Public Finance;

\footnotetext{
${ }^{15}$ Decision no. 332/2014, Article 3 paragraphs (1), (2).

${ }^{16}$ Decision no. 332/2014, Article 5.

${ }^{17}$ Decision no. 332/2014, Article 8 paragraph (1).

${ }^{18}$ Decision no. 332/2014, Article 9 paragraph (1).
} 


\section{Annals of Spiru Haret University \\ Economic Series \\ Since 2000}

ISSN: 2393-1795 ISSN-L:2068-6900

\section{Issue 4/2016}

b) no investment project must begin before the Ministry of Public Finance approves the financing agreement.

If the applicant enterprise requests that the investment should be started before the receipt of the financing agreement, the entire investment will not be eligible. ${ }^{19}$

Businesses eligible for approval of an financing agreement issued by the Ministry of Public Finance must meet several criteria: are registered in Romania, conduct an investment in any sector, prove that have no debt to the state and not received other state aid.

The investments the enterprises make must fulfil the following criteria ${ }^{20}$ :

a) they must be recognized initial investments;

b) they have to lead to the creation of jobs;

c) they should be viable and generate economic efficiency for the enterprise.

The state aid will be paid to the enterprises that received a financing agreement, after they partially or fully perform the eligible expenditure. ${ }^{21}$ year. $^{22}$

An enterprise is allowed to send at most 4 requests for payment of state aid within one calendar

The enterprises that received a financing agreement are bound to start the investment according to the business plan and to inform the Ministry of Public Finance, and if they do not perform the investment these are bound to inform the Ministry of Public Finance within the shortest time possible. ${ }^{23}$

The enterprise is bound to maintain each new job for a term of at least 5 years as of the date it was occupied for the first time, and for 3 years for SME, respectively. ${ }^{24}$

The revocation of the financing agreement takes place in the following situations ${ }^{25}$ :

a) the investment has not started;

b) the minimum number of jobs is not maintained;

c) the bankruptcy is declared or the activity suspended;

d) the location of performance of the investment moves to another region where the maximum intensity of the state aid is lower than the one corresponding to the region where it benefited from state aid.

The state aid paid is to be recovered pro rata to the degree of failure if the enterprise does not observe the requirement regarding the maintenance of the jobs created and if the enterprise does not observe the requirement regarding the maintenance of the initial investment. ${ }^{26}$

The state aid that must be recovered includes the related interest owed as of the date of payment and until the date of recovery. ${ }^{27}$

\section{Conclusion}

One of the main objectives on the agenda of the European Union is the regional development throughout all its Member States, therefore, this objective transfers also to our country, which the Ministry of Public Finances through the General Directorate for state aid strives to level. The poor

\footnotetext{
${ }^{19}$ Decision no. 332/2014, Article 12.

${ }^{20}$ Decision no. 332/2014, Article 16.

${ }^{21}$ Decision no. 332/2014, Article 11 paragraph (1).

${ }^{22}$ Decision no. 332/2014, Article 12 paragraph (2).

${ }^{23}$ Decision no. 332/2014, Article 16 paragraphs (1), (2).

${ }^{24}$ Decision no. 332/2014, Article 18 paragraph (1).

${ }^{25}$ Decision no. 332/2014, Article 20.

${ }^{26}$ Decision no. 332/2014, Article 20 paragraph 4.

${ }^{27}$ Decision no. 332/2014, Article 20 paragraph 6.
} 


\section{Annals of Spiru Haret University \\ Economic Series \\ Since 2000}

ISSN: 2393-1795 ISSN-L:2068-6900

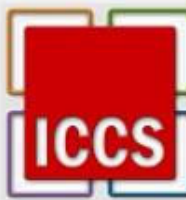

Issue 4/2016

regional development causes different intensities of aid which are given to the less developed areas throughout our country.

One of the biggest discrepancies with about 40 percent intensity is between the country capital region and the east, south east, south west and north east regions.

Regional investment aid policies are not the only tools available to Member States to support investment and job creation in disadvantaged regions. Member States may use other measures, such as improving the infrastructure and quality of education and training, and also of improving the business environment.

Therefore, the Member States should indicate why they choose to grant regional aid for the common goal of fairness and cohesion when introducing a scheme which is not part of an operational program financed by cohesion policy funds.

If the state aid is granted in the form of direct grants, tax incentives or supply of land, goods or services at reasonable prices, the state must demonstrate why other forms of aid are not suitable for granting.

\section{References}

1. Treaty on the Functioning of the European Union, October 2012.

2. Emergency Ordinance no. 77/2014, December 2014.

3. Decision no. 807/2014, September 2014.

4. Decision no. 332/2014, April 2014.

5. Marinescu, Mihaela, Stroe, Lucian, Guide Regarding State Aid, http://www.ajutordestat.ro/documente/GHID\%20PRIVIND\%20AJUTORUL\%20DE\%20STAT_1140r o.pdf 
